at the Chemical Research Laboratory, Teddington, where he carried out his well-known work on sulphatereducing bacteria and associated problems in economic microbiology. This work was notable for the discovery of cytochrome $c_{3}$, the first cytochrome to be found in an anaerobic organism, and for developing techniques for handling and studying sulphate-reducing bacteria. This very successful phase of Dr. Postgate's work was abruptly closed by the disbandment of $\mathbf{K}$. R. Butlin's group in 1959, and Dr. Postgate then undertook and published research on the death of bacteria in conditions of freezing and starvation at the Microbiological Research Establishment, Porton. There he remained until 1963, with an intermission as visiting professor of microbiology in the University of Illinois during 1962-63. In 1963 he joined the Agricultural Research Council to assist Prof. J. Chatt to establish a new Unit of Nitrogen Fixation, now located at the University of Sussex. He will continue to be assistant director of the Unit and his chair is a personal one for the period of his association with the Unit.

\section{Psychology in the University of Newcastle upon Tyne:}

Prof. J. Brown

Dr. J. Brown has been appointed to the chair of psychology in the University of Newcastle upon Tyne with effect from August 1, 1966. Dr. Brown was born in August 1925. He went to Emmanuel Collego, Cambridge, graduating B.A. in 1950 after reading the Moral Sciences Tripos. He gained his Ph.D. degree in 1955, and spent three years on research at Cambridge after graduating and then spent one yoar as a temporary assistant lecturer in the University of Bristol. In 1954 he went to Birkbeck College as assistant lecturer, becoming lecturer in 1956. For the year 1965-66 he has boen appointed visiting associate professor in the University of California (Berkeley). His main interests are in perception, learning and remembering, especially problems of immediate memory.

\section{United Nations Review of Space Science}

The United Nations Committee on the Peaceful Uses of Outer Space was formed in 1959, and has served a useful function as the only international governmental body concerned solely with the subject. In 1963 the Committee decided to sponsor a publication describing the activities of the various international and national organizations concerned with space, and this report has now been published by the United Nations under the title Space Activities and Resources (Pp. v+172. (A/AC. 105/26.) New York: United Nations, 1965. 2 dollars). The report covers first the international governmental organizations which are in some way concerned with space, such as the International Telecommunication Union and the World Meteorological Organization. The next sections describe regional organizations, such as the European Space Research Organization, and non-governmental bodies such as the Committee on Space Research (COSPAR) of the International Council of Scientific Unions. The remainder of the report, about two-thirds of the whole, reviews national space activities. Although the United States and the U.S.S.R. have the largest contributions, there are reports from a total of 37 countries, ranging from Argentina to Yugoslavia, and covering the period up to early 1964. This publication will be welcomed as a work of reference by anyone wishing to sort out the tangled inter-relations between the many international organizations which have decided that space is a subject they cannot afford to ignore. It also provides a useful review of national space activities, especially those of the smaller countries, which are little publicized.

\section{Molecular Pharmacology}

THE first reaction of a scientific reader to a new journal is one of alarm: he has already to look at too many of them and his absorptive capacity is limited. Moreover, the title of the recently issued Molecular Pharmacology is really a tautology. Pharmacology is the science of the examination of the interaction of organic and inorganic molecules with living matter. It follows that all pharmacology is molecular. However, much can be said in defence of this new journal (1, No. 1, July, 1965. Edited by Avram Goldstein. Pp. 1-112. New York: Academic Press, Inc.; London: Academic Press, Inc. (London), Ltd., 1965. Subseription rates: Vol. 1, 1965, 3 issues-International subscribers, 11 dollars; Private subscribers certifying that the journal is for personal use only, 5 dollars). It is being launched under the auspices of the American Society for Pharmacology and Experimental Therapeutics, which is also responsible for the well-known Journal of Pharmacology and Experimental Therapeutics, a publication that carries much material of immediate interest also to the physiologist and clinician. The need may have been felt for a paper that appeals more to the reader whose interests lie mainly in the theoretical aspects of pharmacology. A glance at the first issue shows that it is mainly the development of modern biochemistry (and biophysics) that has made this new venture necessary. The study of enzymes, of proteins in general, of nucleic acids, of cell particles and of cell membranes makes up the main content, and there is also material that deals with transport, with receptor theory and with the genetic code. Molecular Pharmacology earries the sub-title "An International Journal". The members of the advisory board and of the editorial board include scientists from many lands, well known to all workers in this field. The editor is Dr. Avram Goldstein, of Stanford University Medical School. We wish him success in this new enterprise.

\section{Use of CIBA Resins in Ireland}

THE growth potential in the use of synthetic resins and ancillary products in rapidly expanding industries both in Ulster and in the Republic of Ireland has been recognized, since the beginning of 1965 , by the establishment by Ciba (A.R.L.), Ltd., Duxford, Cambridge, of an office and distributing depot in Belfast. Some details of actual developments involving the use of the well-known 'Aerolite' and 'Araldite' products in blockboard and paint manufactures, for example, are given in a recent issue of Technical Notes, entitled "Ciba Resins in Ireland" (Pp. 8. Ciba (A.R.L.), Ltd., Duxford, Cambridge. June 1965). In Northern Ireland there has been, in recent years, a notable expansion in the building industry, especially concerning prefabricated units. One example is the manufacture of wood chipboard, involving the use of large quantities of 'Aerolite' resin each week, at the factory of the Ulster Chipboard Company at Coleraine, County Londonderry ; in this case the raw material is forest thinnings from timber felled from three of the largest forests in Northern Ireland; the process consists of coating the wood chips with resin, pressing the boards, thon sanding on both sides to specified thickness. Other firms using 'Aerolite' adhesive are in large-scale production of such items as panel doors, flush doors, casement windows, garage doors, staircases, school and church furniture. In Eire, similar activities and modern trends in prefabricated timbers are briefly described. In the factories of $\mathbf{T}$. and C. Martin, Ltd., Dublin, a fingerjointing machine produces continuous lengths of jointed timber by gluing selected raw timber of relatively short length with 'Aerodux 500' resorcinol resin adhesive, clamping and pressing, then cutting automatically to the desired length; timbers jointed in this way are eminently suitable as laminated members for structural engineering. Among paint manufacturers, Syntheses, Ltd., Dublin, use 'Araldite' epoxy resin formulations in their production of high-duty paints demanding good mechanical and chemical resistant properties. A further example of this is quoted in the case of Kosangas, Ltd., Dublin, suppliers of 